\title{
Understanding how teacher perceived teaching professionalism
}

\author{
Siti Ina Savira, Suhanadji, Riza Noviana Khoirunnisa \\ Universitas Negeri Surabaya \\ Surabaya, Indonesia \\ inasavira@yahoo.com
}

\begin{abstract}
This research aims to obtain a quantitative description of teacher's perception on the meaning of teaching profession. The data were collected using a questionnaire given to 22 randomly selected subjects of primary schools in Sidoarjo, Indonesia. This research employed descriptive statistical analysis using the Rasch Model. Rasch Model was chosen as data analysis tool since it allows detailed analysis of the person and item being measured. The result showed that teachers generally agree that teaching profession is one of high-status professions, although they differ in justifying the characteristics of a high-status profession, especially for the teaching profession.
\end{abstract}

Keywords-component; Teacher; Teaching; Primary Schools.

\section{INTRODUCTION}

Some of the ongoing issues in education is the issue of teacher professionalism caused by at least three factors; (1) the lack of consensus on the concept of professionalism, particularly in teaching prosfession (Evans, 2008, 2011; Evetts, 2003); (2) teacher professionalism is often determined by external authority (Evans, 2011); and (3) as a result of the many variety of definition of professionalism, the discourses around professionalism is often considered insufficient in theory (Kolsaker, 2008) resulting in the small number of research on that particular topic. Sachs (2016) also suggested that teaching professionalism is shaped dominantly by the external power particularly the government and was initially emerged as a strategy to mobilize teachers. It was also suggested that a new perspective on teacher professionalism is needed to improve its legitimacy and accountability (Sachs, 2016). Therefore, in order to have a better understanding of the construction of teacher professionalism, teacher's perception should be taken into account (Beauchamp \& Thomas, 2009).

In Indonesia, teacher professionalism is often unique in a way that it does not follow the mainstream theory of professionalism (Yuwono \& Harbon, 2010). This finding is supported by many studies that suggested that cultural background often influence how teacher perceived professionalism (Beijaard, Meijer, \& Verloop, 2004; Chandratilake, McAleer, \& Gibson, 2012; Ma \& MacMillan, 1999). Furthermore, traditional view in Indonesia looking at teaching profession as a high social status, however, it does not provide high financial status or academic recognition (Basikin, 2007). On the other side, most research on teacher professionalism in Indonesia is focusing on the issues of teacher competence as regulated in the National Law no.14/2005 (Undang-Undang Guru dan Dosen No.14 Tahun 2005) (Miarso, 2008; Sanaky, 2005; Sauri, 2010). It was also implied by Sachs (2016) that the focus and attention of the government were mainly on teacher's accountability and performance. An unfortunate side of being over emphasizing on performance is that it reduced the meaning of professionalism, which might also underlie the issue of government dominance in regulating teacher professionalism (Beck, 2008).

Hargreaves et al. (2006) suggested that there are at least three aspects that construct the teaching profession, namely teaching status, teaching professionalism, and the reasons for becoming a teacher. This particular study addressed the second aspect that is teaching professionalism from the inside view. This study was limited to the number of subject and scope of the research. The design of this study also affected the depth of data, therefore it required further research to expand the value of this research.

Hargreaves et al. (2006) suggested that teaching profession consists of 5 main dimensions i.e. teaching as a constructive learning, teaching as a trustworthy profession, teaching as a collaboration work with parents and community, and teaching as a profession with autonomy, as well as teaching as delivering standards. However, further analysis had shown that the first two dimension showed a more reliable result (Hargreaves et al., 2006). While Sachs (2016) suggested that there are three factors shaping teacher professionalism namely cultural performance, increased accountability, and standards.

Kolsaker (2008) identified some key characteristic in the academic profession, such as shared values, altruistic attitude toward students, expertise on education, autonomy, advance in science, logic thinking, an evidence-based approach using appropriate concept and theories, and a pursuit of truth.

In Indonesia, teacher professionalism is defined according to the National Law of Teachers No.14/2005 as mentioned earlier. Further explanation about the implementation of this law is elaborated in the Ministry of National Education law (Permendiknas No. 16 Tahun 2007). This regulation is a competency-based approach on teacher professionalism since it is measured based on 4 competencies, namely professional, social, personal, and pedagogic (Permendiknas No. 18 Tahun 2007). This law is also used to determine whether a teacher is eligible or not for teacher certification that will bring certain privilege, such as financial benefit. 
Compared to many discourses on teacher professionalism, there are some remaining issues on those definitions. One of the problematic issues is the meaning of professionalism that requires some degree of autonomy and the rights to selfregulate in controlling a specific occupation (Evetts, 2003; Kolsaker, 2008). Hand in hand to autonomy and professional self-regulation is holding standard, which is consistently considered as one of the characteristics of a profession (e.g. (Hargreaves et al., 2006; Sachs, 2016). Many kinds of literature, however, agree that in terms of teacher professionalism government has lost authority to regulate the teaching practice (Sachs, 2016).

\section{METHOD}

This study used a survey design aiming to gather a large number of data from research population. The population of this research was primary teachers of the state schools in Sidoarjo. There are 10 sample schools which were randomly selected across Sidoarjo in which each school represented by 10 teachers. Although the data collection was conducted in 3 phases, this study reported only the first part of the study.

The first part of the study randomly selected 3 schools where the questionnaires were distributed to 10 teachers. From 30 questionnaires that had been distributed, 25 returned, however, two of them could not be analyzed due to too many missing data. The descriptive statistic of the subject will be presented in Table 1 .

The questionnaire was constructed based on Hargreaves et al. (2006) report which suggested that teaching profession could be understood from three aspects i.e. teaching status, teaching professionalism, and reasons of becoming teachers. The aspects and indicators are presented as follow.

TABle 1. DescriPtive StATISTIC OF SUBJeCt

\begin{tabular}{rrrrrrr}
\hline male & female & $\begin{array}{l}\text { state } \\
\text { teachers }\end{array}$ & $\begin{array}{l}\text { private } \\
\text { teachers }\end{array}$ & $\begin{array}{l}\text { certified } \\
\text { teachers }\end{array}$ & $\begin{array}{l}\text { non-certified } \\
\text { teachers }\end{array}$ & $\begin{array}{l}\text { missing } \\
\text { information }\end{array}$ \\
\hline $27 \%$ & $73 \%$ & $4.55 \%$ & $95.45 \%$ & $81.82 \%$ & $13.63 \%$ & $4.55 \%$ \\
\hline \hline
\end{tabular}

However, this article focused on the second aspect, which is teacher professionalism and its 5 dimensions.
TABLE 2. ASPECT AND INDICATORS OF INSTRUMENT

\begin{tabular}{ll}
\hline \multicolumn{1}{c}{ Aspect } & \multicolumn{1}{c}{ Indicators } \\
\hline Defining status: high professional status and \\
the teaching profession \\
Teacher's status compared to other \\
occupations \\
Teacher's status transformation from time to \\
time \\
Factors that may influence teacher's status in \\
the future
\end{tabular}

The data analysis was conducted using Rasch model by analyzing person and item being measured. The Rasch model was chosen because it allows more detailed analysis of data.

\section{RESULT AND DISCUSSION}

TABLE 3. Teaching professionalism (person measure)

\begin{tabular}{ll}
\hline Person reliability & .84 \\
\hline Item reliability & .86 \\
\hline Cronbach Alpha (person reliability) & .86 \\
\hline
\end{tabular}

Based on the data analysis using Rasch Model, Table 3. showed the statistics summary of person and item measured in this study Planning of Inclusive Learning.

Based on the Rasch Model data analysis, it can be concluded that reliability of person and item in this study was both good (between .81- .90), while Cronbach Alpha showed very good reliability score above .80 . From the result, it can be inferred that the subjects in this study have a consistent response, while the quality of the items in the instrument is also good.

Based on the item measured, it was found that there are 26 items that fell between -2.52 to .90 logit which means items that are most agreed with. Table 4 . displays items with logit measured between -1.37 to -2.52 . 
Table 4. items with lowest logit measure (between -1.37 to - 2.52)

\begin{tabular}{l|l|l}
\hline Number & Item & \\
\hline 1. & 11 & $\begin{array}{l}\text { A good teacher evaluates his/her teaching practice and learns from teaching } \\
\text { experiences. }\end{array}$ \\
\cline { 2 - 4 } & 10 & In teaching, creativity is very important. \\
\hline 2. & 7 & For teachers, professional development is very important. \\
\hline 3. & 13 & $\begin{array}{l}\text { Teachers should always be ready to learn new teaching and learning } \\
\text { methods. }\end{array}$ \\
\hline
\end{tabular}

Based on the analysis on the lowest logit of the items measured, it can be inferred that teachers mostly agreed with pedagogic items, which is closely related to the teaching practice. Teachers, for example, believed that evaluating teaching practice, creativity, and professional development is important to improve teaching. To be compared, table 5 is summarizing the highest logit of the items measured.

\begin{tabular}{|c|c|c|}
\hline Number & Item & \\
\hline 1. & 28 & $\begin{array}{l}\text { Professionalism that consists of pedagogic, personality, and social } \\
\text { competence is often difficult to be achieved by teachers. }\end{array}$ \\
\hline 2. & 9 & $\begin{array}{l}\text { Centralization of educational assessment may reduce teacher } \\
\text { professionalism. }\end{array}$ \\
\hline 3. & 4 & Teaching is an autonomous profession. \\
\hline 4. & 29 & $\begin{array}{l}\text { The most important thing in teaching professionalism is the ability to manage } \\
\text { classes and teach according to the curriculum and nothing else should matter. }\end{array}$ \\
\hline 5. & 32 & $\begin{array}{l}\text { I think on present days, there is still a huge gap between government's } \\
\text { attention and the demand to teachers. }\end{array}$ \\
\hline 6. & 5 & Centralization on curriculum may reduce teacher's autonomy. \\
\hline
\end{tabular}

The results showed that teachers were actually quite confident that they may not have any difficulties in establishing pedagogic, personality, and social competence. However, it should be noted that the teachers in this study are certified and public school teachers, which means that they are government officials. One of interesting findings from this study is that teachers tended to disagree that teaching profession is an autonomous profession. This might explain why teachers do not think that centralization of educational assessment and centralization of the curriculum may risk teaching profession autonomy because they tend to believe that the profession is not autonomous. This might be the result of government's dominance in constructing teaching profession for decades. Bjork (2004) found that Indonesian teachers valued being a civil-servant rather than an 'autonomouseducator' that makes them put obedience to the government as a priority. The same reason had failed many teachers to adapt to the Local Content Curriculum back in 1994 where teachers were expected to take leadership to interfere with the curriculum (Bjork, 2004). It was assumed that the long historical background of teachers identity that had been shaped by the government to be the cause (Bjork, 2006). This might also explain the more accepted items that do not seem to show the need to be more autonomous in their work.

The results of research in both cases of curriculum modification have been applied in the form of modification, substitution, omission, and duplication. These findings are in conformity with the Guidelines for the Implementation of Inclusive Education (2011: 18) in which alternative types of school curriculum included.

Another finding of this study is that there were some different responses between male and female teachers. Male teachers were more likely to agree with items $8,10,21$, which are 'personal integrity is an important thing for teachers', 'in teaching, creativity is important, 'teacher's main task is to improve quality standards'. Whereas female teachers particularly prefer item 11, 'good teachers evaluate their teaching practice and learn from their teaching experience'. Another bias item between male and female teachers was shown in item 30, 'professional teachers are teachers that have a good mastery of the subject matter, with a proper teaching method'. That particular item was quite a favorite among the female teachers while it was not the case for the males. On the contrary, item 15, 'effective teaching should involve parents as an equal partner on child education', was not favorable for male teachers, while it was quite liked by the females. From the result, it can be inferred that male and female teachers might have a different response for the same item. It was assumed that male teachers emphasizing more on personal quality in teaching, while females seemed to have a broader view on deciding what effective teaching is.

Martin and Yin (1997), found that male teachers are particularly more "controlling, dominant, and interventionists" than female teachers which may affect their attitudes and beliefs regarding teaching. Being controlling, dominant and interventionists might mean that male teachers tend to rely and believe in their own decision in teaching while minimizing intervention from other parties, including parents. However, male as well as female teachers believed that fellow teachers are important for effective teaching. Therefore, male teachers might perceive teaching as a more autonomous profession than female teachers, while female teachers tended to emphasize more on pedagogic competence to improve teaching quality. The graph that illustrates bias between male and female responses is presented in Diagram 1.

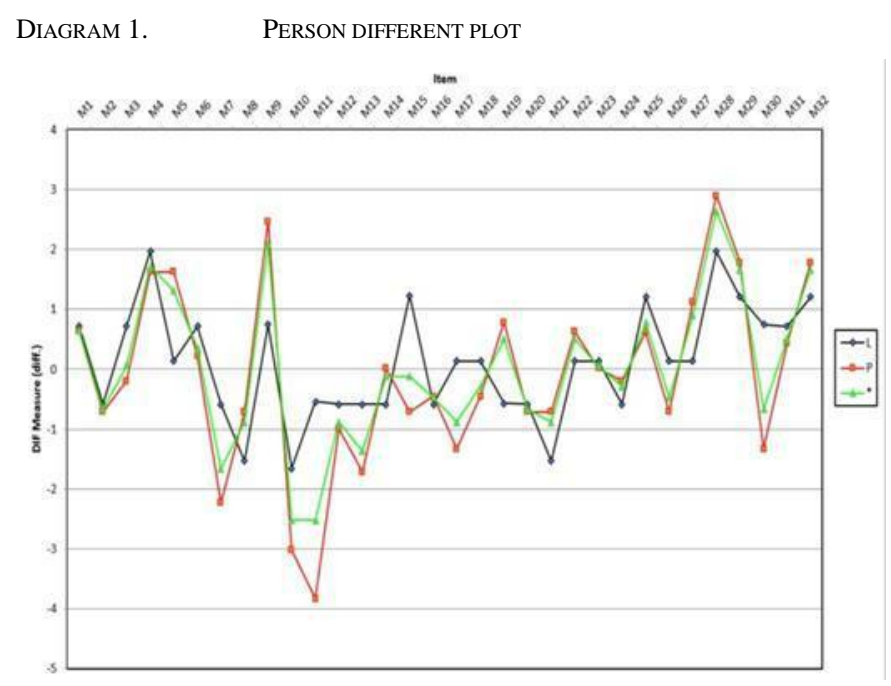

\section{CONCLUSION}

This study found that Indonesian teachers tend to perceive their profession as not autonomous, while emphasis more on pedagogic competence. On the other hand, autonomy is one characteristic of a profession. There was also an indication, however, that male and female teachers had a different perspective on teaching, where male teachers tended to attribute effective teaching to personal quality, while female teachers considered more about various factors. Teaching 
might also be more autonomous for male teachers compared to females.

\section{REFERENCES}

[1] Baskin, B.2007. Vigor, dedication, and absorption: Work engagement among secondary school English teachers in Indonesia.

[2] Beauchamp, C., \& Thomas, L.2009. Understanding teacher identity: An overview of issues in the literature and implications for teacher education. Cambridge journal of education, 39(2), 175-189.

[3] Beck, J.2008. Governmental professionalism: Re-professionalising or de-professionalizing teachers in Eng-land.
British journal of educational studies, 56(2), 119-143.

[4] Beijaard, D., Meijer, P.C., \& Verloop, N.2004. Reconsidering research on teachers' professional identity. Teaching and teacher education, 20(2), 107-128

[5] Bjork, C.2004. Decentralisation in education, institutional culture and teacher autonomy in Indonesia. International review of education, 50(34), 245-262.

[6] Bjork, C.2006. Transferring authority to local school communities in Indonesia: ambitious plans, mixed results Educational decentralization (pp. 129-147): Springer.

[7] Chandratilake, M., McAleer, S. \& G Gibson, J.2012. Cultural similarities and differences in medical professionalism:
a multi-region study. Medical education, 46(3), 257-266.

[8] Evans, L. 2008. Professionalism, professionality and the development of education professionals. British journal of educational studies, 56(1), 2038 .
[9] Evans, L.2011. The 'shape'of teacher professionalism in Eng-land: Professional standards, performance management, professional development and the changes proposed in the 2010 White Paper. British educational research journal, 37(5), 851-870.

[10] Evetts, J.2003. The sociological analysis of professionalism: Occupational change in the modern world. International Sociology, 18(2), 395-415.

[11] Hargreaves, L., Cunningham, M., Everton, T., Hansen, A., Hopper, B., McIntyre, D., . . . Wilson, L.2006. The status of teachers and the teaching profession: Views from inside and outside the profession. Cambridge: University of Cambridge.

[12] Kolsaker, A.2008. Academic professionalism in the manager-alist era: A study of English universities. Studies in Higher Education, 33(5), 513525 .

[13] Miarso, Y.2008. Peningkatan kualifikasi guru dalam perspektif teknologi pendidikan. Jurnal Pendidikan Penabur, 7(10), 66-76.

[14] Martin, N.K., \& Yin, Z.1997. Attitudes and Beliefs regarding Classroom Management Style: Differences between Male and Female Teachers.

[15] Sachs, J.2016. Teacher professionalism: why are we still talking about it? Teachers and Teaching, 22(4), 413-425.

[16] Sanaky, H.A.H.2005. Sertifikasi dan profesionalisme guru Di era reformasi pendidikan. Jurnal Pendidikan Islam, 1, 1-13.

[17] Sauri, S.2010. Membangun karakter bangsa melalui pembinaan profesionalisme guru berbasis pendidikan nilai. Jurnal Pendidikan Karakter, 2(2).

[18] Yuwono, G.I., \& Harbon, L. 2010. English teacher profession-alism and professional development: Some common issues in Indonesia. Asian EFL Journal, 12(3), 145-163. 